\title{
On the stratigraphy of Upper Palaeolithic types and type groups
}

\author{
Karl J. Narr \\ Institut für Vor- und Frühgeschichte, Universität Bonn, 5300 Bonn, Germany \\ Correspondence: Markus Fuchs (markus.fuchs@geogr.uni-giessen.de) \\ Relevant dates: $\quad$ Published: 17 December 2021
}

How to cite: $\quad$ Narr, K. J.: On the stratigraphy of Upper Palaeolithic types and type groups, DEUQUA Spec. Pub., 3, 27-34, https://doi.org/10.5194/deuquasp-3-27-2021, 2021.

Special issue statement. This article is part of a special issue published on the occasion of the 70th anniversary of $E \& G$ Quaternary Science Journal (EGQSJ). The special issue celebrates the journal's notable contribution to Quaternary research by revisiting selected milestone articles published in the long history of EGQSJ. The German Quaternary Association (DEUQUA) presents translations of the originals and critical appraisals of their impact in tandem anniversary issues of DEUQUASP and EGQSJ, respectively.

Original article: https://doi.org/10.3285/eg.02.1.06

Tribute: https://doi.org/10.5194/egqsj-70-2132021

Translators: Clare Bamford, Markus Fuchs, Michael Bolus and Henrik Rother

The traditional division of the Upper Palaeolithic into $\mathrm{Au}-$ rignacian, Solutrean and Magdalenian has been substantially modified by the research of the last decades. Breuil (1912) already recognised that "Early" and "Late" Aurignacian are linked by certain phenomena that are generally lacking in the "Middle" Aurignacian. The gap between "Middle" and "Late" Aurignacian was particularly emphasised by Bayer (1928). Instead of the latter, he spoke of an "Aggsbachian" for Eastern and Central Europe, which at a time when a "Late Aurignacian" rooted in the Middle Aurignacian is said to have lived on in Western Europe, had penetrated as far as the Rhine and only later asserted itself in France. In addition, he recognised that the Olschewian needed to be detached from the Aurignacian as a special facies (Bayer, 1929). These views were linked by Bayer to his well-known biglacial system and together with it were later generally rejected. In
France, Peyrony (1933) expanded Breuil's idea and united the "Early" and "Late" Aurignacian into a "Perigordian", which supposedly developed without gaps in Western Europe, but in between the older and younger stages of the latter the Aurignacian established itself (in a narrow sense = Breuil's "Middle Aurignacian"). Garrod (1938), on the other hand, came to the view that the late "Perigordian" originated outside Western Europe. She distinguished a Châtelperronian in Western Europe (= Breuil's "Early Aurignacian" $=$ Peyrony's "Early Perigordian") over which the Aurignacian coming from the East (= Breuil's "Middle Aurignacian"), and which in turn was overlain by the Gravettian (= Breuil's "Late Aurignacian" = Peyrony's "Late Perigordian" = Bayer's "Aggsbachian"), also of Eastern origin. The Solutrean is such a complicated problem that it cannot be discussed here in detail. The Magdalenian was subdivided by Breuil (1912) into 6 stages, of which the first three have recently been redefined according to their type content and separated as Proto-Magdalenian (Cheynier, 1951).

The dissolution of Breuil's "Aurignacian" has, of course, also rendered the dispute about its Eastern or Western origin irrelevant. In particular, the fact that the "Early Aurignacian" (in Breuil's sense) is only widespread in Western Europe, the "Middle Aurignacian" in Western, Central and western Eastern Europe, and the "Late Aurignacian" even from Spain to Siberia, can no longer be used to support a Western origin of the entire complex. However, we can make use of this fortunate circumstance in the elaboration of the type inventories of the individual groups or periods, for which Garrod's terminology will be used in the following. The Aurignacian could hardly have absorbed a substrate effect from the Châtelperro- 
nian in Central Europe. Likewise, the Gravettian, which represents the oldest Upper Palaeolithic culture in the Ukraine, will appear more distinctly there than, for example, in southern France with its manifold overlays.

Based on the find material from southern France, characteristic for the Châtelperronian are Châtelperron points (Fig. 1,4) and blades with retouched oblique or transverse end (Fig. 1, 11 and 21). For the Aurignacian, carinated endscrapers (Fig. 1, 44) and bone points with split bases (Aurignac points) (Fig. 3,1) are characteristic based on Central European finds. For the Eastern Gravettian, Gravette points (Fig. 1, 5-7), backed bladelets (Fig. 1, 8-9), micro knives (Fig. 1, 12), blades and burins with retouched oblique or concave ends (Fig. 1, 11, 18-21, 33-34), shouldered points of the Eastern European type (Fig. 2, 1), as well as the dihedral burins with endscraper base (Fig. 1, 35 and 43) stand out. ${ }^{1}$ The Olschewian has in common with the Aurignacian blades with circumferential lateral retouching (Fig. 1, 1). The stone tool industry, however, is generally quite poorly developed in favour of excellent bone manufacture. Bone points with a solid base (Lautscher points) (Fig. 3, 3), are predominantly characteristic, and these also occur in the Aurignacian. In a younger stage of the Western European Arignacian (II), the Aurignac points are replaced again by points with a solid base, most of which have a rhombic outline, originally with a flat (II), then oval (III) and finally round cross-section (IV) (Fig. 3, 3). In the third stage of the Western Aurignacian, the points with forked bases (Fig. 3, 2) also appears for the first time, experiencing their main peak in the Magdalenian. Further characteristic features of the Western Aurignacian are the busked burins (Fig. 1,36) and the strangled blades (Fig. 1, 2-3), which occur only rarely in Central Europe (e.g., Krems).

The Gravettian of Western Europe can be divided into two main facies, one of which (Font Robert facies) is distinguished from the other (Gravette facies) by the occurrence of shouldered points (Fig. 2, 2, more rarely 2,1) and tanged points $(2,3)$. A later horizon carries in large numbers the so-called Noailles burins (Fig. 1, 31-32, 38) and saws (perhaps developed from the strangled blades of the Aurignacian) (Fig. 1, 13-16). The former of these scarcely occurs in Central Europe, the latter somewhat more frequently.

For the Proto-Magdalenian, three sub-groups could be established on the basis of certain stone tool forms, such as the so-called Raclettes (Fig. 1, 17 and 27) and "Burins à coche" (Proto-Magd. I), micro-burins (Fig. 1, 39), microlithic endscrapers on blades (Fig. 1, 46), micro-knives (Fig. 1, 12) and micro-Gravette points (Fig. 1, 10) (Proto-Magd. II) and certain triangular tools (Fig. 1, 25-26) (Proto-Magd. III). How-

\footnotetext{
${ }^{1}$ Since the enticingly abundant material from southern France has so far mostly been chosen as the starting point for separating out type groups, the type last referred to, which also occurs in certain Aurignacian levels, was not recognised there as an element of the Gravettian.
}

ever, these are likely to have more facial than regional stratigraphic value. It also seems uncertain whether they correspond completely with the stages I-III worked out by Breuil (1912) on the basis of the bone tools.

The Magdalenian IV-V can be described as Early, High and Late Magdalenian after the Proto- Magdalenian has been separated out. The individual stages are mainly characterised by the different harpoon shapes (Fig. 3, 5-9). High and Late Magdalenians also carry the so-called parrot beaks (Fig. 1, 45) and experience a vigorous "renaissance" of numerous Gravettian forms, e.g., Gravette points (Fig. 1, 5-7), backed bladelets (Fig. 1, 8-9), micro-knives (Fig. 1, 12), blades and burins with retouched oblique and concave ends (Fig. 1, 1821, 33-34, 37), dihedral burins with endscraper base (Fig. 1, 35 and 43) and endscrapers on blade without retouched edges (Fig. 1, 28-30, 40-41, 42 and 47). Moreover, saws can be found in the Proto- Magdalenian and Magdalenian (Fig. 1, 13-15), while rectangular backed bladelets which are retouched on all edges (Fig. 1, 24) seem to occur mainly in the High and Late Magdalenian, while simple rectangular backed bladelets (Fig. 1, 22) are not rare even in the Eastern Gravettian.

The problems of origin, migration and direction of influx of the individual typological complexes can only be solved on the basis of a chronology that is as precise and detailed as possible. The temporal overlaps can be recognised to a large extent by evaluating the joint occurrence of the elements of different groups in a closed archaeological assemblage. However, the time lags in individual areas make the application of an "objective" chronometer, free of typological considerations, appear desirable. Such a chronometer is provided by geological dating, for which the loess and cave sediments are of particular importance corresponding to the main find locations.

A starting point for their parallelisation is provided by the last Antiquus fauna, above which two thick layers with frost debris can be detected in the cave sediments, and which furthermore seems to belong to the period between Soergel's older and younger loess (= loess I and II/III according to Bayer, 1928, 1929 and Freising, 1951). However, in many places (e.g., La Ferrassie, Mauern) the upper layer with frost debris is divided by a weaker zone of loamy and finely grained sediments, through which a separate, apparently relatively short cold period can be distinguished. If one equates this two-part layer with frost debris and the upper young loess with the youngest morphological witnesses of an ice advance, i.e., the Würm and Weichsel moraines, it is plausible to think of a correlation of the upper and lower parts of the layer with frost debris with the inner and outer young moraines, i.e., Soergel's Würm II and III. The extent to which the underlying layer with frost debris and the lower young loess correspond to a stage which has been overrun or which is to be separated from the association of the "Riss" moraines and the Warta ice margin need not be of interest here (cf. Narr, 1951). 


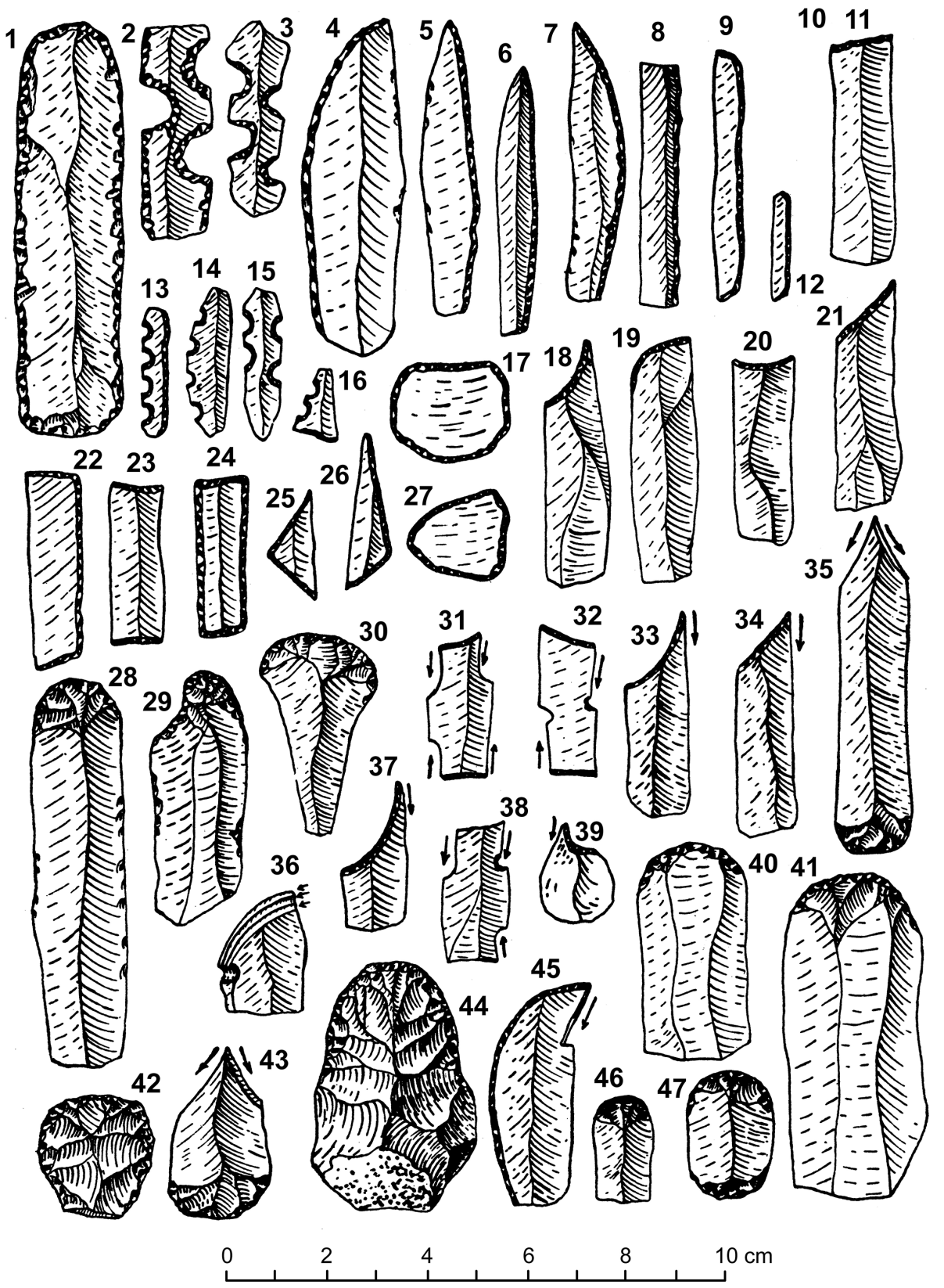

Figure 1. Types of Upper Palaeolithic stone artefacts (explanation in text).

On the other side, it is essential that also in the upper young loess a period of interruption of loess deposition can be detected at the Rhenish loess sites (e.g., Metternich, Mainz) by a thin, loamy layer, which is, however, not comparable with the Krems and Göttweig soil formation.

For Austria and Bohemia-Moravia, the "Paudorf" zone is considered to have a similar position (most recently Brandtner, 1950). In southern German loess, Freising (1951) described tundra gley soils as evidence of a cool climate with high precipitation. To what extent these phenomena can be paralleled with each other and with the weak intermediate layer within the layer with frost debris of the caves remains to be investigated. As a working hypothesis, however, such a correlation should be taken as a basis in the following, the viability of which will then have to be proven. Furthermore, the cold-oceanic early phase of the Würm II glaciation, which is also recognisable in the cave deposits, is important for the detailed subdivision (Büdel, 1950). The fact that the composition of the cave sediments is more complicated than shown in the diagram below does not need to be emphasised (cf. Lais, 1941). Taking archaeological aspects into account, the table was supplemented by a stage classification of the Up- 

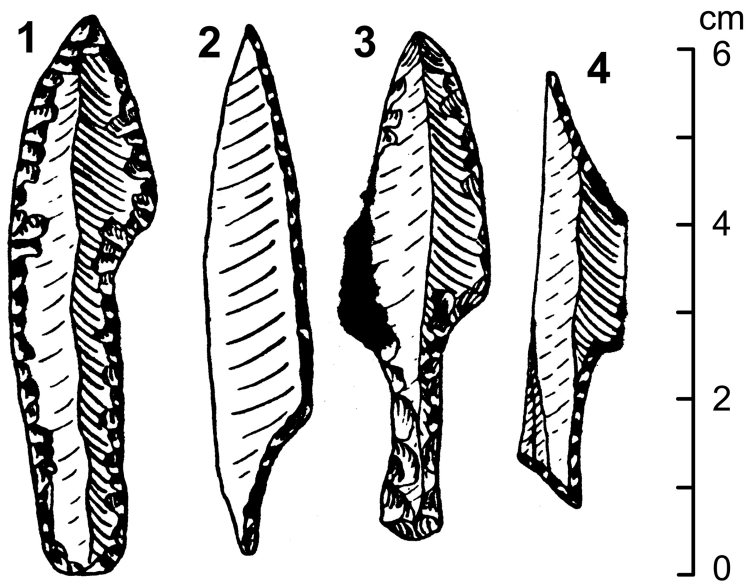

Figure 2. Upper Palaeolithic shouldered and tanged points.

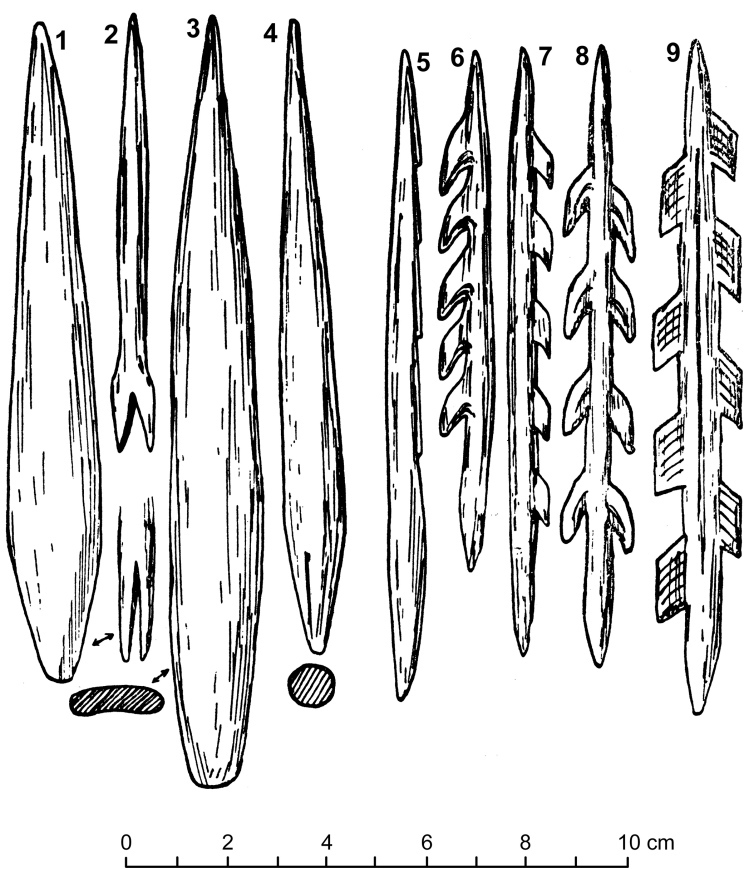

Figure 3. Types of Upper Palaeolithic artefacts made of bone, antler or ivory (explanation in text).

per Palaeolithic, which is to be understood in the sense of a purely stratigraphic-chronological horizontal subdivision. The transition from stage 1 to 2 is given by the change from a temperate interglacial to a cold climate. Stage 2 can be divided into two parts by the transition from the cold-oceanic Early Glacial to the cold-arid High Glacial. The separation of 2 and 3 is more clearly possible in Western European caves than in loess sequences, and is marked in the former by a slight climatic improvement (also palaeontologically indicated). The boundary of $3 a$ and $3 b$ can so far only be recognised in some caves in southern France, where it corresponds archaeologically to the replacement of the Aurignacian II by the Gravettian or Aurignacian III in the "regular profiles". Substage 3c, however, can also be grasped by an interruption of the loess deposit. The cut between stages $4 \mathrm{a}$ and $4 \mathrm{~b}$ is marked by the cessation of loess formation. How this relates to the end of the Würm III layer with frost debris remains unclear. Likewise, the temporal relation of the end date of these deposits with the beginning of the temperate-subarctic final phase of the older tundra period must remain open. The replacement of $4 \mathrm{~b}$ by $4 \mathrm{c}$ can currently only be determined micropalaeontologically ( $=$ to the onset of the Allerød period).

By means of this - naturally still very imperfect - classification and a division into geographic provinces of finds, we arrive at a kind of spatial-temporal coordinate system into which the type assemblages that often occur in individual regions at different times can be incorporated. Individual evidence for such a classification would go beyond the scope of this essay, for which a cursory overview may suffice. (For more detailed explanations, we must refer to the - hopefully imminent - publication of an as yet unpublished work by the author on the Rhenish Upper Palaeolithic).

The Olschewian occurs in the Würm I/II interstadial period. The more recent ideas about the division of the Late Pleistocene make it possible to date the high alpine sites of this group in this way as well. In two places (Vogelherd, Wildscheuer) a sparse Olschewian lies below the Aurignacian. Whether this stratigraphic relationship can be generalised remains to be seen. The genetic relationships of the Aurignacian and Olschewian are also still unclear. The $\mathrm{Au}-$ rignacian is already well represented in Central Europe in stage 1 , but also extends into stage 2 . In this period, however, the Gravettian already appears in Eastern and Central Europe. Some of its elements are almost always admixed to the Aurignacian sites of stage 2, which allows a typological distinction of this gravettoid Aurignacian from the pure Aurignacian of stage 1. In France, the Aurignacian can be clearly identified at the end of stage $2 \mathrm{a}$ at the earliest. Here it overlies the Châtelperronian, which extends from stage 1 into stage 2a. The Châtelperronian occasionally contains Aurignacian elements, with the help of which the Châtelperronian of stage $2 \mathrm{a}$ can apparently be detected in a typological way. ${ }^{2}$ At the same time, this circumstance makes the presence of Aurignacian in Western Europe in the same stage probable, even if it cannot yet be directly proven (apart from the Riviera).

As already mentioned, the Gravettian first appears in Central and Eastern Europe in stage 2. In Western Europe it is not yet attested in pure form, but only by individual elements occurring in the Aurignacian complex. (However, these could

\footnotetext{
${ }^{2}$ For example, the eponymous site Châtelperron has Aurignac points. However, since this site has not yet been geologically dated, an interpretation of this find combination as an isolated occurrence of Aurignacian forms in stage 1 of Western Europe cannot be excluded.
} 


\begin{tabular}{|c|c|c|c|c|c|c|}
\hline \multicolumn{2}{|c|}{ Climate and glacial stages } & Cave sediments & & Loess & \multicolumn{2}{|c|}{$\begin{array}{c}\text { Upper } \\
\text { Palaeolithic } \\
\text { stages }\end{array}$} \\
\hline Allerød & \multirow{3}{*}{$\begin{array}{l}\text { Temperate } \\
\text { Cold- } \\
\text { continental }\end{array}$} & \multirow{3}{*}{$\begin{array}{c}\text { ??? } \\
\text { Coarse, angular } \\
\text { frost debris }\end{array}$} & & & \multirow{3}{*}{4} & c \\
\hline \multirow{2}{*}{$\begin{array}{l}\text { Würm III } \\
\text { (Recessional } \\
\text { end moraine) }\end{array}$} & & & & & & $\mathrm{b}$ \\
\hline & & & \multirow{6}{*}{$\begin{array}{l}\text { Upper } \\
\text { Young } \\
\text { Loess }\end{array}$} & Pure loess & & a \\
\hline \multirow{2}{*}{\multicolumn{2}{|c|}{ Cool-humid oscillation }} & \multirow{2}{*}{$\begin{array}{l}\text { Loamy and fine- } \\
\text { grained layers }\end{array}$} & & \multirow{2}{*}{$\begin{array}{l}\text { Disruption of loess } \\
\text { formation }\end{array}$} & \multirow{3}{*}{3} & c \\
\hline & & & & & & $\mathrm{b}$ \\
\hline \multirow{3}{*}{$\begin{array}{l}\text { Würm II } \\
\text { (Terminal } \\
\text { end moraine) }\end{array}$} & \multirow{2}{*}{$\begin{array}{l}\text { Cold- } \\
\text { continental }\end{array}$} & \multirow{2}{*}{$\begin{array}{l}\text { Coarse, angular } \\
\text { frost debris }\end{array}$} & & \multirow{2}{*}{ Pure loess } & & a \\
\hline & & & & & & $b$ \\
\hline & $\begin{array}{l}\text { Cold- } \\
\text { oceanic }\end{array}$ & $\begin{array}{l}\text { Loamy and small- } \\
\text { sized layers }\end{array}$ & & $\begin{array}{l}\text { Loess, reworked by } \\
\text { solifluction }\end{array}$ & 2 & $a$ \\
\hline Warm & eriod & $\begin{array}{l}\text { Predominantly } \\
\text { loamy layers }\end{array}$ & soil $f$ & $\begin{array}{l}\text { Göttweig } \\
\text { rmation period }\end{array}$ & & \\
\hline
\end{tabular}

also have moved with the already gravettoid Aurignacian of Stage 2 from Central to Western Europe and are therefore not sufficient evidence for the presence of a pure Gravettian). On the contrary, it does not seem to have reached Western Europe in general in stage 2, with the exception perhaps of some sites on the Riviera (Mentone, La Baume Périgaud: with Aurignacian elements). Few finds seem to belong to stage $3 \mathrm{a}$. However, richer Gravettian occurrences in France can only be proven for $3 \mathrm{~b}$. At many sites, the Gravettian facies is overlain by the Font Robert facies, but the reverse relationship is also documented (e.g., Vachons). The Gravettian continues to survive into Stage $3 c$ and perhaps the beginning of 4 in Western and Central Europe, and even longer in Eastern Europe. This astonishing duration of the Gravettian makes a chronological subdivision desirable. In Willendorf II, the lower strata do not yet carry shouldered points, but these are well represented in horizons $8-9$, which probably belong to stage $2 \mathrm{~b}$. Whether this can be generalised and used to distinguish between an Early and a High Gravettian is still quite questionable. In contrast, a later horizon, already related to the Proto- Magdalenian, seems to stand out relatively well, which seems to belong from the end of stage $3 b$ to $3 c$ and perhaps the beginning of 4 . It is characterised above all by the Noailles burins (e.g., Mainz, Předmost, Honči, Puškari III), which are very numerous in Western Europe but rare in Central and Eastern Europe, and the saws (e.g., Munzingen, Unterwisternitz), which are also well represented in Central Europe.

This Late Gravettian is closely linked to the problem of the so-called "loess Magdalenian", for which the Munzingen site is usually cited as a key witness. For the Magdalenian character, it is mainly the saws that are cited. However, in Western Europe they occur in addition to the Proto-Magdalenian and Magdalenian also in the Late Gravettian and Solutrean and can therefore not be taken as a sure sign for the involvement of Proto- or Early Magdalenian. A presence of Proto- or Early Magdalenian has not yet been proven with certainty in Central and Eastern Europe. Occasionally appearing ancient elements (e.g., the well-known ornaments of the Placard type in the Maszycka cave) can be explained without difficulty as remnants of the High and Late Magdalenian. Of course, this does not mean that sites such as Munzingen cannot be chronologically be paralleled with the Proto- or Early Magdalenian. On the contrary, Proto- and Early Magdalenian seem to overlap with the Late Gravettian also in Western Europe, where these two complexes are connected not only by saws but also by the occurrence of triangles. ${ }^{3}$

In France, Magdalenian $\mathrm{Vb}$ and VIa belong to the layer with frost debris of stage 4a (Peyrony, 1938, p. 281). In Central Europe it also occurs in layers with frost debris. However, the Magdalenian V cannot be proven with certainty. ${ }^{4}$ The Magdalenian VIa may belong to the very end of stage $4 \mathrm{a}^{5}$ and in any case still extends into the already temperatesubarctic final stage of the Würm III (Gross, 1951) and per-

\footnotetext{
${ }^{3}$ Both types are possibly derived from a Mediterranean facies of the Gravettian ("Grimaldian").

${ }^{4}$ In the Kastlhäng cave, however, only one harpoon of the Magd. V-type was recovered. In fact, it is the only harpoon ever found at this site. However, it is not uncommon for this type to be associated with Magd. VI forms (e.g., Andernach), so that a single find does not prove anything. The separation of the layers in the Keßlerloch is also highly questionable (Bandi, 1947, p. 149). A good example of the survival of ancient forms is the Petersfels Cave, which probably belongs to the end of $4 \mathrm{a}$ or to $4 \mathrm{~b}$, where red deer and roe deer already appear, thereby witnessing a more temperate climate. Currently there is no clear evidence for the presence of Magd. IV-V in Central Europe.

${ }^{5}$ Kimball and Zeuner date the Magdalenian to the "end of Würm II until the beginning of Würm III". However, only stages associated with Würm moraines are designated as Würm I-III, i.e., phenomena which, according to Soergel's and the terminology used here (cf. also Narr, 1951), only begin with Würm II. It would therefore be necessary to test whether Kimball and Zeuner's maximum age
} 
haps into the Allerød (Schwabedissen, 1949). The Hamburg group, which is mainly characterised by a special type of shouldered points (Fig. 2,4), should probably be placed in about the same period.

At this point, a digression into the field of historical problems of the Late Palaeolithic may be allowed to illuminate the great importance of chronology for the elucidation of such questions. If we look at the chronological relationships, we find that there is a high probability of a west-east spread of the Magdalenian. Likewise, the table below speaks for an east-west direction of the expansion of the Aurignacian:

\begin{tabular}{|c|c|c|c|}
\hline \multicolumn{2}{|c|}{ Stage } & France & Central Europe \\
\hline \multirow{3}{*}{3} & $\mathrm{C}$ & ? ? & \\
\hline & $\mathrm{b}$ & : : : : & \\
\hline & a & $::::::::::$ & \\
\hline \multirow{2}{*}{2} & $\mathrm{~b}$ & $::::::::::::::::$ : & $::::: \ldots$ \\
\hline & a & \multirow{2}{*}{$\ddot{\cdots} \vec{m}$ ? } & $:::::::::::::::$ : \\
\hline 1 & & & 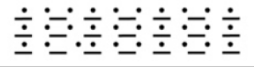 \\
\hline \multicolumn{4}{|c|}{$\begin{array}{ll}\text { Explanation: } & :::::::=\text { Aurignacian } \\
& \\
& \beth \beth \Xi=\text { Olschewian }\end{array}$} \\
\hline
\end{tabular}

The time table for the Gravettian makes a general eastwest direction likely:

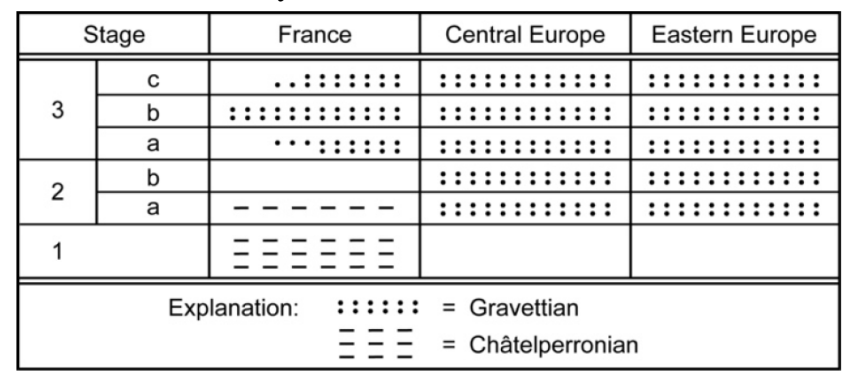

One may like to use these chronological relations for a decision in the controversy between Peyrony and Garrod about the origin of the western Gravettian. Peyrony argues for a local derivation from The French Châtelperronian, Garrod for an immigration from the east. If one were to answer the question of the derivation of the western Gravettian simply in Garrod's sense with a glance at the table, it would be all too easy; for asked in this way, the question is mistaken. In view of the differences between Gravette and Font Robert facies, it should not be raised and solved in such a general way. Since the Gravette facies is characterised by the absence of certain types, such as the shouldered and tanged points (and the so-called Venus statuettes), one could explain it as a phenomenon of impoverishment of the Font Robert facies. However, this is not quite satisfactory, since in most cases it is older than the latter. For the Font Robert facies, however, one cannot ignore the participation of Eastern elements because of the types mentioned. Under these circumstances, the idea suggests itself to connect the Font Robert facies to the

should not be interpreted as the end of Würm III in the sense applied here.
Eastern Gravettian, but the Gravette facies to the Châtelperronian of France and to draw the dividing line in such a way that we would have on the one hand a "Perigordian" (= Châtelperronian + Gravette facies), and on the other hand an "Aggsbachian" (= Eastern Gravettian and quintessence of the Font Robert facies). On the other hand, it has to be considered that a direct connection of Châtelperronian and Gravettian has not yet been proven, especially since the socalled "Perigordian III", considered by Peyrony as a connecting link, has certain forms (lames foliacées) in common with the Font Robert facies. ${ }^{6}$ The Central and Eastern European occurrences of Noailles burins and saws are probably signs of a Western European backflow, in the context of which the "import" of Mediterranean molluscs can perhaps be included (e.g., Mainz, Krems).

A still rather mysterious phenomenon are the leaf point industries, which will only be briefly discussed here. They run parallel to the blade industries and often appear mixed with them. In Central Europe (especially in Hungary) the ProtoSolutrean is at least partly contemporaneous with the Aurignacian of stage 1, the High and Late Solutrean with the Aurignacian or Gravettian of stages 2 and 3. In Western Europe the Solutrean is regionally intercalated between the Gravettian and Magdalenian, but is spatially limited and temporally equivalent to parts of the industries mentioned. Its individual stages have the same names as in Central Europe, but have only local significance and must not be interpreted as an expression of simultaneity. On the whole, the Western European Solutrean seems to lie in stage 3, probably only in 3b-c. The origin of the Solutrean is usually thought to be Hungary, but recently Africa has also come into consideration. Here, however, the chronological priority of Central Europe has a decisive word to say. If one wants to derive the Western European Solutrean from Africa, then one must consider it as a convergence phenomenon to the Central European Solutrean. If, however, one maintains a genetic connection, then the possibility of an African origin no longer applies.

All these questions are very subtle problems in which chronology has a decisive say, but other criteria must also be given due consideration. Particularly important are factors that lead beyond the purely typological approach, since

\footnotetext{
${ }^{6}$ Peyrony's "Perigordian II" is not identical with our Châtelperronian of level 2. The author prefers to count only the La Ferrassie E' of Peyrony's "Perigordian II" as Châtelperronian. The other "Perigordian II" sites seem to be relatively recent, diverse mixtures of Aurignacian and Gravettian elements (e.g., Bos del Ser, Dufour).

${ }^{7}$ The strangled blades of Krems may also belong into this context. The influence of the Mediterranean Gravettian (Grimaldi) was probably also instrumental in the formation of the ProtoMagdalenian II-III. This Gravettian facies includes, among other things, strangled blades from which the saws were possibly developed. These may have been transferred from here to the southern French Proto-Magd. II-III on the one hand, and into the Central European Late Gravettian on the other, and therefore need not be regarded as Magdalenian influence in the latter group.
} 
cultural flows or even population movements do not necessarily have to be identical with the spread of types or type groups. Especially in the European Upper Palaeolithic, the analysis of economic and settlement forms and above all of art styles, as well as the anthropological position of the bearers of culture and the connection to certain climatic zones, seems to yield a picture of cultural history that deviates from the "schematism of the type table". In spite of the sometimes quite far-reaching shifts of the ergological complexes, the counterplay of two large cultural areas in Western Europe on the one hand, and in Central and Eastern Europe on the other, remains perceptible. In this respect, there are still many problems to be clarified, but they cannot be discussed now, as we are primarily concerned here with the stratigraphic foundations.

In the context of a journal intended to promote cooperation between the various disciplines involved in Quaternary research, it may seem justified and desirable to consider the question of what can be gained from the subject treated here for such cooperation. The invaluable services that geological stratigraphy offers to the cultural-historical work of the prehistorian through the provision of solid dating probably need no further explanation after the above excursus. But what about the other way round? Can such investigations also be a support and help for geological research? That depends above all on whether and to what extent archaeological reference specimens may be used in the sense of type fossils.

Methodological reservations of a material and formal nature arise from the nature of artefacts and the danger of circular reasoning. The first arises from the fact that the relics of past cultures, as the results of creative intellectual activity, cannot be pressed into a physical scheme, but rather - in accordance with the free will of their makers - have something arbitrary attached to them. In practice, however, this is largely eliminated by tradition and a tendency to persistence. Left aside the fact that, in addition to chronologically more usable forms, there are also completely indifferent forms which is also the case with the fossils - we must nevertheless reckon with an irregularity in the life span, different ages in individual areas and an erratic occurrence. If the second objection is that artefacts are dated by means of the geological determination of the age of the find layers and then the dating of other deposits is deduced from such artefacts, then of course the danger of a "vicious circle" must be admitted. In principle, however, this is also the case with palaeontological forms. In the case of palaeontological forms, however, this danger is largely reduced by the fact that they are rooted in biological-physical processes. In the case of archaeological type fossils, on the other hand, this can only happen to a lesser extent through the narrowest possible morphological delimitation of a type, scrupulous attention to its chronological value or lack of value, the consideration of the largest possible number of confirmed findings and the assessment of regional differences, which make it advisable to move with such conclusions within the narrowest possible geographical framework. The further we move away from this basis, the more uncertain - and dangerous - the results become.

A particularly important point appears to be the extraordinary longevity of certain types. The Châtelperron points, for example, are by no means limited to the Châtelperronian, but extend into the Mesolithic. The Gravette points are basically only a narrower and finer development of the Châtelperron points. Technically coarse and large Gravette points therefore easily revert to the shape of Châtelperron points. Châtelperronian, which occurs in stage 1 in Western Europe, is absent in Central and Eastern Europe. As long as it is not proven there, we have to assume that in Central and Eastern Europe Châtelperron points can only occur from stage 2 onwards as - if one may say so - "atavistic" phenomena within the Gravettian. This is at the same time a second essential aspect, namely the consideration of regional shifts in the chronology of certain type fossils. It also applies to the same extent, for example, to the blades with retouched oblique ends or the Aurignac points. The following table schematically illustrates the limitation of a selection of types that can be used for chronology according to the current state of research:

\begin{tabular}{|c|c|c|c|}
\hline \multicolumn{2}{|c|}{ Stage } & Western Europe & Central Europe \\
\hline \multirow{3}{*}{4} & C & \multirow[b]{3}{*}{$======$} & \multirow[b]{3}{*}{$=======$} \\
\hline & b & & \\
\hline & a & & \\
\hline \multirow{3}{*}{3} & c & \multirow{3}{*}{$X|X| X I X I X|X| X$} & \multirow{3}{*}{$\times \times \times \times \times \times \times \times x$} \\
\hline & $\mathrm{b}$ & & \\
\hline & $\mathrm{a}$ & & \\
\hline \multirow{2}{*}{2} & $\mathrm{~b}$ & 11111111111111 & 11111111111111 \\
\hline & a & $+\overline{+}++++++$ & $-\mathrm{O}-\mathrm{O}-\mathrm{O}-\mathrm{O}-\mathrm{O}-\mathrm{O}-$ \\
\hline \multicolumn{2}{|l|}{1} & 00000000 & ++++++++ \\
\hline
\end{tabular}

Explanation:

○ $\bigcirc$ Terminus post quem: Châtelperron points, blades with retouched transversal or oblique end

+++ Terminus post quem: Aurignac points, carinated endscrapers

$\ldots$ _ $\ldots$ Terminus post quem: Gravette points, dihedral burins with endscraper base

$\mathrm{X} \times \mathrm{X}$ Terminus post quem: Noailles burins, saws

$==1$ Terminus post quem: Double row harpoons

। I I I Terminus post quem: Triangles

/ / / / / Terminus ante quem: Aurignac points

It does not need to be pointed out that the more types that can be considered, the more certain the dating becomes. If, for example, a certain layer in Central Europe contains dihedral burins with endscraper base, it belongs to stage 2 or a younger horizon. Aurignac points date a find to stage 1 or 2 , but if both occur together, then only the overlapping area in the respective duration of the two type fossils comes into question, i.e., stage 2 .

In addition to this possibility of at least approximate dating of layers of uncertain position by typological means, we shall finally attempt to verify the correlation of the upper horizons of the cave sediments and the loess with the help of archaeological stratigraphy, which was assumed at the beginning as a working hypothesis. While the Magdalenian seems to 
be completely absent in the loess area of northern France, a Late Magdalenian is found in loess sites in Central Europe, but never in a deposition that proves its contemporaneity with the loess formation. Rather, it lies in the upper parts of a loess loam or at the border of loess and humus, i.e., at depths to which it may have come from the surface. In Andernach, it is not likely to predate the pumice deposit of the Allerød by much (Gross, 1951). In cave sediments of France and southern Germany, it still belongs to layers with frost debris, but in the latter area it is already associated with a fauna that points to the subarctic warming of the Late Glacial period, during which loess deposition certainly no longer took place.

If we go back further, we can also see that the horizon with Noailles burins and saws in France begins in the loamy intermediate layer (stage 3c) and perhaps a little earlier. In loess locations in Central Europe it is noticeable in the interruption period of the upper young loess or immediately before the restart of loess deposition (e.g., Mainz, Munzingen, Unterwisternitz). For the cave sites we have to leap to the French occurrences mentioned above (apart from a thick, Noailles-like burin, layer C of Mauern, probably belonging to stage 4a). At this distance, of course, a temporal shift is to be expected. However, since this is an assemblage of Western European origin, this would at most have an effect on a somewhat younger dating of the Central European layers. Such an assumption, however, should hardly be necessary, since the comparison of the loess and cave sediments assumed above already seems to indicate a certain chronological priority of the west. In view of the methodological concerns mentioned above, these arguments cannot have any definitive authority; however, it can at least be said that the archaeological stratigraphy does not contradict the parallelisation assumed in Table 1 . It may therefore serve as a heuristic principle for future geological-palaeontological investigations, which alone may be decisive.

Review statement. This paper was edited by Markus Fuchs.

\section{References}

Bandi, H. G.: Die Schweiz zur Rentierzeit: Kulturgeschichte der Rentierjäger am Ende der Eiszeit, Huber, Frauenfeld, 217 pp., 1947.

Bayer, J.: Das zeitliche und kulturelle Verhältnis zwischen den Kulturen des Schmalklingenkulturkreises während des Diluviums in Europa, Die Eiszeit, 5, 1928.

Bayer, J.: Die Olschewakultur, eine neue Facies des Schmalklingenkulturkreises in Europa, Eiszeit und Urgeschichte, 6, 83-100, 1929.

Böhmers, A.: Die Höhlen von Mauern, Palaeohistorica, 1, 1951.

Brandtner, F.: Über die relative Chronologie des jüngeren Pleistozäns Niederösterreichs, Archaeologia Austriaca, 5, 1950.

Breuil, H.: Les subdivisions du paléolithique supérieur et leur signification, Congrès international d'anthropologie et d'archéologie préhistoriques, 14, 165-238, 1912.

Büdel, J.: Die Klimaphasen der Würmeiszeit, Naturwissenschaften, 37, 438-449, https://doi.org/10.1007/BF00638074, 1950.

Cheynier, A.: Les Industries Proto-Magdaléniennes, Bull. Soc. Préhist. Fr., 48, 190-192, https://doi.org/10.3406/bspf.1951.2860, 1951.

Freising, H.: Neue Ergebnisse der Lößforschung im nördl. Württemberg, Jahrbuch der geologischen Abteilung des württembergischen statistischen Landesamtes, 1, 54-59, 1951.

Garrod, D. A. E.: The Upper Paleolithic in the Light of Récent Discovery, P. Prehist. Soc., 4, 1-16, https://doi.org/10.1017/S0079497X00021113, 1938.

Gross, H.: Die moorgeologische Datierung des jüngeren Magdalénien in Deutschland, E\&G Quaternary Sci. J., 1, 166-171, https://doi.org/10.3285/eg.01.1.16, 1951.

Kimball, D. and Zeuner, F. E.: The Terraces of the Upper Rhine and the Age of the Magdalénian, Univ. of London, Inst. of Archeol. Occas., Paper 7, London, 1946.

Lais, R.: Über Höhlensedimente, Quartär, 3, 56-108, 1941.

Narr, K. J.: Terrassen, Löße und paläolithische Kulturen, Germania: Anzeiger Der Römisch-Germanischen Kommission Des Deutschen Archäologischen Instituts, 29, https://doi.org/10.11588/GER.1951.45845, 1951.

Peyrony, D.: Les industries "aurignaciennes" dnas le basin de la Vézère, Bull. Soc. Préhist. Fr., 30, 1933.

Peyrony, D.: Le Perigordien et l'Aurignacien (Nouvelles Observations), Bull. Soc. Préhist. Fr. 33, 616-619, https://doi.org/10.3406/bspf.1936.5461, 1936.

Peyrony, D.: La Micoque, Les fouilles récentes - Leur signification, Bull. Soc. Préhist. Fr., 35, 257-283, https://doi.org/10.3406/bspf.1938.12316, 1938.

Schwabedissen, H.: Hamburg-Rissen, ein wichtiger Fundplatz der frühen Menschheitsgeschichte, Hammaburg, 2, 81-90, 1949. 